\title{
Atmospheric data over a solar cycle: no connection between galactic cosmic rays and new particle formation
}

\author{
M. Kulmala ${ }^{1}$, I. Riipinen ${ }^{1,2}$, T. Nieminen ${ }^{1}$, M. Hulkkonen ${ }^{1}$, L. Sogacheva ${ }^{1,3}$, H. E. Manninen ${ }^{1}$, P. Paasonen ${ }^{1}$, \\ T. Petäjä ${ }^{1}$, M. Dal Maso ${ }^{1}$, P. P. Aalto ${ }^{1}$, A. Viljanen ${ }^{3}$, I. Usoskin ${ }^{4}$, R. Vainio ${ }^{1}$, S. Mirme ${ }^{5}$, A. Mirme ${ }^{5}$, A. Minikin ${ }^{6}$, \\ A. Petzold ${ }^{6}$, U. Hõrrak ${ }^{5}$, C. Plaß-Dülmer ${ }^{7}$, W. Birmili ${ }^{8}$, and V.-M. Kerminen ${ }^{3}$ \\ ${ }^{1}$ University of Helsinki, Helsinki, Finland \\ ${ }^{2}$ Carnegie Mellon University, Pittsburgh, Pennsylvania, USA \\ ${ }^{3}$ Finnish Meteorological Institute, Helsinki, Finland \\ ${ }^{4}$ Sodankylä Geophysical Observatory (Oulu Unit), University of Oulu, Sodankylä, Finland \\ ${ }^{5}$ University of Tartu, Tartu, Estonia \\ ${ }^{6}$ Deutsches Zentrum für Luft- und Raumfahrt (DLR), Wessling, Germany \\ ${ }^{7}$ Meteorologisches Observatorium Hohenpeissenberg, Deutscher Wetterdienst (DWD), Hohenpeissenberg, Germany \\ ${ }^{8}$ Leibniz Institute for Tropospheric Research, Leipzig, German
}

Received: 21 September 2009 - Published in Atmos. Chem. Phys. Discuss.: 13 October 2009

Revised: 1 February 2010 - Accepted: 9 February 2010 - Published: 18 February 2010

\begin{abstract}
Aerosol particles affect the Earth's radiative balance by directly scattering and absorbing solar radiation and, indirectly, through their activation into cloud droplets. Both effects are known with considerable uncertainty only, and translate into even bigger uncertainties in future climate predictions. More than a decade ago, variations in galactic cosmic rays were suggested to closely correlate with variations in atmospheric cloud cover and therefore constitute a driving force behind aerosol-cloud-climate interactions. Later, the enhancement of atmospheric aerosol particle formation by ions generated from cosmic rays was proposed as a physical mechanism explaining this correlation. Here, we report unique observations on atmospheric aerosol formation based on measurements at the SMEAR II station, Finland, over a solar cycle (years 1996-2008) that shed new light on these presumed relationships. Our analysis shows that none of the quantities related to aerosol formation correlates with the cosmic ray-induced ionisation intensity (CRII). We also examined the contribution of ions to new particle formation on the basis of novel ground-based and airborne observations. A consistent result is that ion-induced formation contributes typically significantly less than $10 \%$ to the number of new
\end{abstract}

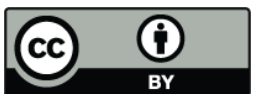

Correspondence to: M. Kulmala (markku.kulmala@helsinki.fi) particles, which would explain the missing correlation between CRII and aerosol formation. Our main conclusion is that galactic cosmic rays appear to play a minor role for atmospheric aerosol formation events, and so for the connected aerosol-climate effects as well.

\section{Introduction}

Clouds, especially aerosol-cloud interactions, constitute currently the largest uncertainty in predicting the behavior of the Earth's climate system (IPCC, 2007; Baker and Peter, 2008; Clement et al., 2009). Besides various effects of anthropogenic aerosols on clouds, an issue that has raised considerable interest is the potential connection between galactic cosmic rays, clouds and climate. This connection, as outlined by Dickinson (1975) and reviewed later by Carslaw et al. (2002), involves changes in the intensity of cosmic ray ionization in the atmosphere due to variations in solar activity, with subsequent changes in the abundance and properties of aerosols capable of modifying cloud properties.

Since the work by Svensmark and Friis-Christensen (1997), the climatic role of cosmic rays has been investigated mainly by analyzing empirical relations between the cosmic ray intensity and cloud cover (Sun and Bradley, 2002; Palle, 2005; Harrison and Stephenson, 2006; Sloan

Published by Copernicus Publications on behalf of the European Geosciences Union. 


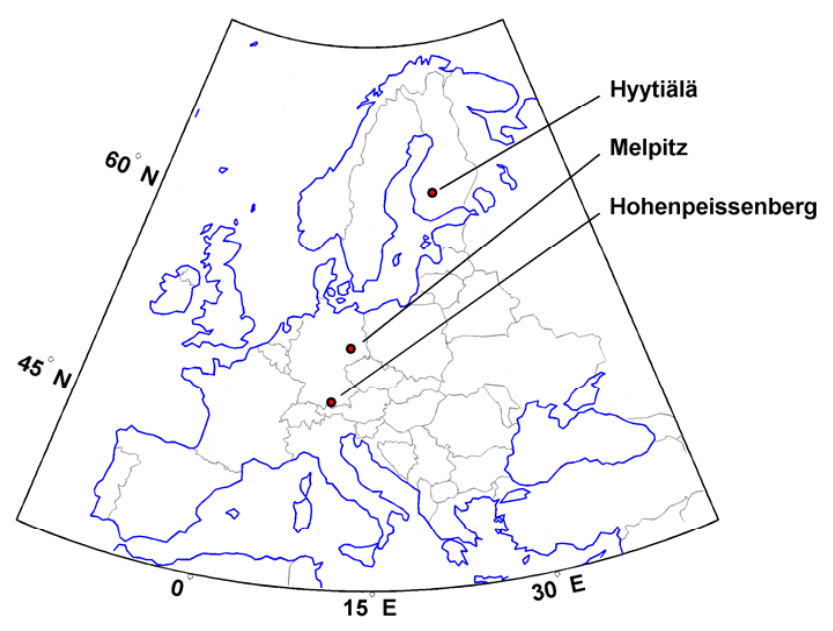

Fig. 1. Location of three ground-based measurement sites studied in this work (Hyytiälä in Finland, and Melpitz and Hohenpeissenberg in Germany).

and Wolfendale, 2008) or other cloud properties (Kristjansson et al., 2008; Svensmark et al., 2009). The results from these studies have been ambiguous (Usoskin and Kovaltsov, 2008). An alternative way to approach the problem is to look at whether variations in CRII could influence atmospheric aerosol populations. In this regard, the most plausible effect is the so-called "ion-aerosol clear-air mechanism", in which ions produced by cosmic rays enhance the rate of atmospheric aerosol formation and eventually the concentration of cloud condensation nuclei (CCN; Carslaw et al., 2002).

Until now, our understanding on the connection between galactic cosmic rays, ions and atmospheric aerosol formation has relied solely on few model investigations (Kazil et al., 2006; Yu et al., 2008; Pierce and Adams, 2009). Here we present the first observation-based study on this subject. By noting that (i) ion production is driven by galactic cosmic rays over most of the atmosphere (Dickinson, 1975), (ii) aerosol formation via ion-induced nucleation is thermodynamically easier than via neutral pathways (Winkler et al., 2008) and (iii) aerosol formation is a frequent phenomenon in the atmosphere (Kulmala et al., 2004), we make the following hypothesis: if CRII was one of the major factors contributing to atmospheric ion numbers and if these ions had a significant effect on particle formation and growth, a connection between CRII and aerosol formation should be observed at any location. We study this hypothesis by comparing the intensity of atmospheric particle formation and particle number concentrations recorded at a boreal forest site in Hyytiälä, Finland, to corresponding CRII and geomagnetic activity at the same site. The correlations between CRII, geomagnetic activity and atmospheric particle numbers were further compared to solar radiation and its connection to particle formation. To study the fraction of ion-induced nucleation of total particle formation rates, we present results on the relative fraction of charged to neutral sub- $3 \mathrm{~nm}$ particles and their formation rates in Hyytiälä and two other European sites (Hohenpeissenberg and Melpitz) as well as during airborne measurement campaign over central Europe.

\section{Methods}

\subsection{SMEAR II}

The SMEAR II (Station for Measuring Forest EcosystemAtmosphere Relations) station is located in a rather homogenous Scots pine (Pinus sylvestris L.) stand on a flat terrain at Hyytiälä Forestry Field Station of the University of Helsinki $\left(61^{\circ} 51^{\prime} \mathrm{N}, 24^{\circ} 17^{\prime} \mathrm{E}, 181 \mathrm{~m}\right.$ above sea level, see Fig. 1) $220 \mathrm{~km}$ North-West from Helsinki. The station represents boreal coniferous forest, which covers $8 \%$ of the earth's surface and stores about $10 \%$ of the total carbon in terrestrial ecosystem. The biggest city near the SMEAR II station is Tampere, which is about $60 \mathrm{~km}$ from the measurement site with about 200000 inhabitants. Kulmala et al. (2001) and Hari and Kulmala (2005) have described the station and its operation in detail.

\subsubsection{Aerosol size distribution measurements with the DMPS}

Continuous particle size distribution measurements in the 3-1000 nm size range have been carried out with a Differential Mobility Particle Sizer (DMPS) system since January 1996 at the SMEAR II station. The setup in Hyytiälä is a twin-DPMS, consisting of two separate DMPS systems: the first DMPS measures particles starting from $3 \mathrm{~nm}$ (applying a TSI-3025 CPC), and the second from $10 \mathrm{~nm}$ (with a TSI-3010 CPC). The sheath flows in the system are maintained using a closed-loop arrangement (Jokinen and Mäkelä, 1997). Over the course of the years, the sampling location of the instrument and individual components out of which the DMPS comprises of has varied. Between 1996 and 2004 the DMPS was sampling from $2 \mathrm{~m}$ above ground inside the canopy (Mäkelä et al., 1997, 2000). Aalto et al. (2001) clarified that the size distribution below and above canopy was similar and new particle formation events were observed at both levels. Currently, the aerosol sample is collected from $8 \mathrm{~m}$ above ground level through a 8.5-m-long tube with an inner diameter of $10 \mathrm{~cm}$ and a flow velocity of $2361 \mathrm{~min}^{-1}$. The sample is conducted to the DMPS system from the center of this tube through a 35-cm-long secondary tube with $6 \mathrm{~mm}$ inner diameter. The sample flows further in the two DMAs are $11 \mathrm{~min}^{-1}$ and $41 \mathrm{~min}^{-1}$. For a detailed description of the DMPS setup applied in Hyytiälä, we direct the reader to Aalto et al. (2001). 


\subsubsection{Analysis of the DMPS data}

The collected DMPS size distribution data was divided into particle formation event days, non-event days and undefined days according to the classification scheme introduced by Dal Maso et al. (2005). In general, a day is classified as a particle formation event day if it shows an appearance of a new nucleation mode which is present for several hours and grows continuously during the course of the day. If no traces of a fresh nucleation mode are seen, a day is classified as a non-event day. Days that did not clearly belong to either of the afore-mentioned categories were classified as undefined. Recently Buenrostro Mazon et al. (2009) refined the classification for years 1996-2006, and found that some undefined days shared some features with particle formation event days, whereas others were clearly closer to non-event days. Buenrostro Mazon et al. (2009) named the undefined days that resembled particle formation event days "failed events". Particle formation and growth rates on particle formation event days were calculated as described by Dal Maso et al. (2005).

\subsubsection{Calculation of the Cosmic Ray Induced Ionization intensity (CRII)}

We evaluated the cosmic-ray induced ionization using the recent CRAC:CRII model of Usoskin and Kovaltsov (2006), which employs Monte Carlo simulations of the atmospheric cascades produced by the primary cosmic rays incident on the top of the atmosphere. The simulations are based on the CORSIKA (http://www-ik.fzk.de/corsika/) cosmicray air shower program extended with the FLUKA (http: //www.fluka.org) particle-physics package for lower energy $(<80 \mathrm{GeV} /$ nuc) hadronic interactions. The primary cosmicray flux is modeled by the force-field approximation (Gleeson and Axford, 1968; Usoskin and Kovaltsov, 2006), where the heliospheric modulation of galactic cosmic rays is parametrized through the heliospheric modulation potential, $\phi$. This approximation shows good agreement with direct measurements of the cosmic-ray flux on occasional spacecraft and balloon flights at energies of several hundred $\mathrm{MeV} /$ nucleon (Usoskin et al., 2005), i.e., high enough to produce measurable effects at sea level. The exact values of the modulation potential, obtained by fitting the data from the World neutron monitor network, are available at (http:// cosmicrays.oulu.fi/phi/phi.html). The model gives CRII as a tabulated function of two parameters: the modulation potential $\phi$ and the atmospheric depth, $d$. The atmospheric depth (the amount of the air mass overburden) is directly related to the atmospheric barometric pressure, $p$, at each location by $d\left(\mathrm{~g} \mathrm{~cm}^{-2}\right)=1.019492 \times p(\mathrm{hPa})$. Using these values, the value of CRII for each epoch and location is linearly interpolated from the table. The geomagnetic effects on the cosmic-ray flux can be neglected in the detailed comparison of nucleation and CRII , because of the high-latitude location of the Hyytiälä station, where the geomagnetic cut-off rigidity is below the effective atmospheric cut-off. We present data also for two German stations (detailed description can be found below). For these stations with higher geomagnetic cutoff rigidities, the values of CRII would be slightly lower than for Hyytiälä, and their temporal variation would have a lower amplitude. The data from these stations were not, however, analyzed in detail against CRII.

This method of evaluating CRII was verified and tested against direct measurements and other models (Bazilevskaya et al., 2008; Usoskin et al., 2009) and has been shown to be valid within $10 \%$ accuracy in the troposphere. The model may overlook some minor effects, such as solar energetic particle events and local anisotropy of cosmic rays, but these effects can be neglected for the sea-level at the studied time scales (months-years).

\subsubsection{Geomagnetic activity}

In addition to the cosmic-ray ionization, also changes in the atmospheric electric circuit, driven by geomagnetic activity, have been proposed as sources of climate variations (e.g., Tinsley, 2000). In addition to CRII, we have considered geomagnetic activity as a possible driver of the atmospheric nucleation. The $K$ index is a 3-h, quasi-logarithmic local indicator of geomagnetic activity relative to a quiet-day curve for the recording site. It measures the deviation of the more disturbed horizontal component on the scale from 0 to 9 (Mayad, 1980; Rangarayan, 1989). The $K p$ index characterises global activity as averaged from the $K$ indices of 13 mid-latitude $\left(44-60^{\circ}\right)$ observatories. The $a a$ index is converted back to amplitude values from the $K$ indices of two antipodal midlatitude sites (Canberra, Australia and Hartland, England). For further information on the geomagnetic parameters see e.g. http://isgi.cetp.ipsl.fr/lesdonne.htm.

The range indicator $\Delta B$ is the difference between the maximum and minimum values of a magnetic field component during a given period (here, $3 \mathrm{~h}$ ). Contrary to $K, K p$ and $a a$, it is truly uniquely expressed in physical units (nT). The range indicator can be calculated for each observatory. In this work parameter $\Delta B$ was obtained from a close-by measurement to the Hyytiälä station (at the Nurmijärvi Geophysical Observatory of the Finnish Meteorological Institute, $60.50 \mathrm{~N}$, $24.65 \mathrm{E}$ ), and it corresponds to the difference between the maximum and minimum observed values of the geographically northward magnetic field component during each threehour period. It represents an indicator of local geomagnetic activity, whereas the index data represent more global geomagnetic variability at mid-latitudes. A further motivation for the use of publicly available index data is to facilitate easier comparison with other studies of geomagnetic activity in relation to atmospheric parameter variations. 


\subsubsection{Global radiation, brightness parameter $P$ and cloudiness}

Global radiation was measured using the Reemann TP 3 pyranometer (wave length range $300-4800 \mathrm{~nm}$ ) at $18 \mathrm{~m}$ above ground and averaged over half an hour. If no global radiation data existed, it was estimated based on a linear correlation between global radiation and Photosynthetically Active Radiation (PAR, measured $18 \mathrm{~m}$ above ground with LiCor LI-190SZ quantum sensor, range 400-700 nm).

The brightness parameter was defined as the ratio between the integrals

$$
P=\int_{\text {sunrise }}^{16} R_{\mathrm{obs}} / \int_{\text {sunrise }}^{16} R_{\mathrm{theor}}
$$

where $R_{\text {obs }}$ refers to the observed global radiation and $R_{\text {theor }}$ to theoretical radiation estimate obtained by scaling the solar constant with a season-dependent factor, as described by Hartman (1994).The integration was done from theoretical sunrise $\left(R_{\text {theor }}>0\right)$ to $16: 00$ in the afternoon, to account for the daytime radiation. The threshold values of $P$ for "cloudy" and "bright" days used in this work were 0.3 and 0.5 , respectively. These values were chosen based on a comparison between the $P$ values and cloudiness data estimated from satellite observations (Sogacheva et al., 2008).

\subsection{Additional measurements}

\subsubsection{Air Ion Spectrometer (AIS)}

The AIS (Mirme et al., 2007) measures mobility distributions of both negative and positive air ions in the range from 3.16 to $0.00133 \mathrm{~cm}^{2} \mathrm{~V}^{-1} \mathrm{~s}^{-1}$. This corresponds to a mobility diameter range of approximately 0.8 to $40 \mathrm{~nm}$. In essence, the AIS consists of two cylindrical Differential Mobility Analyzers (DMAs) equipped with insulated electrometer rings. Sampled ions are collected on the electrometer rings in 21 electrical mobility fractions simultaneously for both polarities. The AIS has been measuring at the SMEAR II station in Hyytiälä since the year 2003.

\subsubsection{Neutral cluster and Air Ion Spectrometer (NAIS)}

The NAIS is an instrument that measures the distribution of air ions in the electric mobility range from 3.16 to $0.0013 \mathrm{~cm}^{2} \mathrm{~V}^{-1} \mathrm{~s}^{-1}$ (0.8 to $42 \mathrm{~nm}$ ) and the distribution of aerosol particles in the size range from 1.5 to $42 \mathrm{~nm}$ (Kulmala et al., 2007). It is a successor to the Air Ion Spectrometer (AIS, Airel Ltd., Estonia; Mirme et al., 2007) and has been measuring at the SMEAR II field station since the year 2006.

\subsubsection{Ground-based measurements: Hohenpeissenberg}

The Meteorological Observatory Hohenpeissenberg (MOHp) operated by the German Weather Service is located approximately $40 \mathrm{~km}$ north of the Alps at $985 \mathrm{~m}$ a.s.1. $\left(47^{\circ} 48^{\prime} \mathrm{N}, 11^{\circ} 01^{\prime} \mathrm{E}\right.$, Fig. 1$)$ on top of a solitary mountain which extends about $300-400 \mathrm{~m}$ above the surrounding area. The landscape is dominated by forest and agricultural pastures. There are no significant industrial sources in the vicinity. The nearest city, Munich, is approximately $70 \mathrm{~km}$ to the northeast of the site. On more than $70 \%$ of each year the predominant wind direction is WSW with advection of relatively clean rural background air. Since 1994 the station contributes to the Global Atmosphere Watch (GAW) program of the World Meteorological Organization (WMO), featuring the monitoring of a broad range of meteorological and atmospheric chemical parameters including $\mathrm{OH}$ (www.dwd.de/gaw), hence providing a platform for detailed research (Birmili et al., 2000; Rohrer and Berresheim, 2006; Hock et al., 2008). A NAIS instrument was operated 20 July 2007-28 December 2008 in the top floor of the building at about $18 \mathrm{ma}$ a.g.l. which roughly corresponds to the canopy level of the closest trees on the steep slopes of Hohenpeissenberg.

\subsubsection{Ground-based measurements: Melpitz}

The atmospheric research station Melpitz $\left(51^{\circ} 32^{\prime} \mathrm{N}\right.$, $12^{\circ} 54^{\prime} \mathrm{E}, 87 \mathrm{~m}$ a.s.l., Fig. 1) is located in Northern Saxony, $41 \mathrm{~km}$ northeast of Leipzig (Germany). The station itself is on flat grasslands, surrounded by agricultural land. The site can be described as being situated in a rural polluted continental area. At Melpitz, continuous measurements of aerosol particles, gas phase concentrations $\left(\mathrm{O}_{3}, \mathrm{NO}, \mathrm{NO}_{2}\right.$, and $\left.\mathrm{SO}_{2}\right)$, and meteorological parameters have been conducted since 1991. Particle size distributions have been measured continuously across a size range of $3-800 \mathrm{~nm}$ by a twin-DMPS system since 2003. NAIS measurements were made between April 2008 and May 2009. Additional details on the suite of aerosol measurements are available in Engler et al. (2007) and Birmili et al. (2008).

\subsubsection{Airborne measurements: Falcon}

NAIS was operated airborne during the EUCAARILONGREX campaign aboard the Falcon 20 of DLR, which is a twin jet aircraft used for atmospheric research with an endurance of about 4 hours and a maximum flight altitude of about $12 \mathrm{~km}$ (see Mirme et al., 2010). The scientific payload of the DLR Falcon during the EUCAARILONGREX campaign is summarized in Table 1. It consisted of the DLR WALES lidar system and a combination of in situ instruments for the characterization of aerosol properties (Minikin et al., 2003; Weinzierl et al., 2009) as well as transport tracers (carbon monoxide and ozone). A FSSP-300 


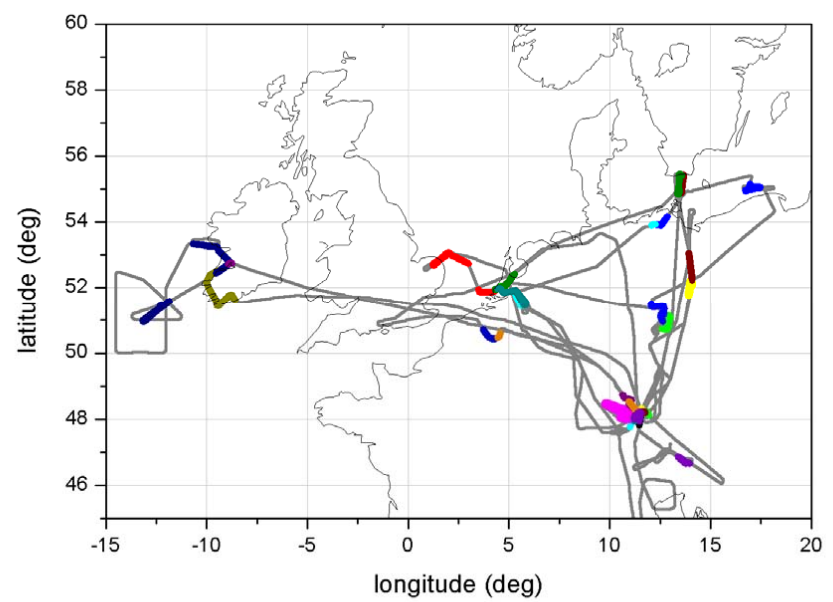

Fig. 2. Map of DLR Falcon flight tracks during the EUCAARILONGREX campaign in May 2008. Highlighted are flight sections inside the boundary layer, which indicate the locations where vertical profiles were obtained for in-situ measurements.

aerosol spectrometer probe was used to define the in-cloud sequences during this campaign (using a threshold criterion for the number concentration of particles larger than $3 \mu \mathrm{m}$ ).

The DLR Falcon performed altogether 16 flights in the EUCAARI-LONGREX instrument configuration between 2 May and 24 May 2008. The general flight strategy was to perform flight legs for lidar measurements in the upper troposphere and fly in-between vertical stacked vertical profiles including short (4-5 min) constant level flight legs at several altitudes for vertical soundings with the in-situ instruments between boundary layer and upper troposphere. The flights were performed mostly in coordination with the British FAAM BAe-146 research aircraft. Both aircrafts were operating during the campaign out of the airport of Oberpfaffenhofen in Southern Germany. Flights focused on the region of Central Europe north of the Alps and the Atlantic off the West coast of Ireland (Fig. 2).

\subsubsection{Operation of NAIS on Falcon}

We developed a new version of NAIS, which is able to measure at varying altitudes from inside an aircraft. The particle size range of the new instrument is kept invariant of air pressure and temperature changes. This is achieved by automatic adjustment of the sheath airflows to compensate for the variability of the particle mobility due to changes in the air pressure and temperature. The effect of temperature variations is considered small because of warming in the sampling line. The sample air volume flow-rate is automatically kept constant. The measurement rate of the instrument was increased by an order of magnitude to improve the time resolution.

The Airborne NAIS flew on-board the DLR Falcon 20 aircraft in total of 48.5 flight hours during the EUCAARILONGREX campaign in May 2008. We used a sample air

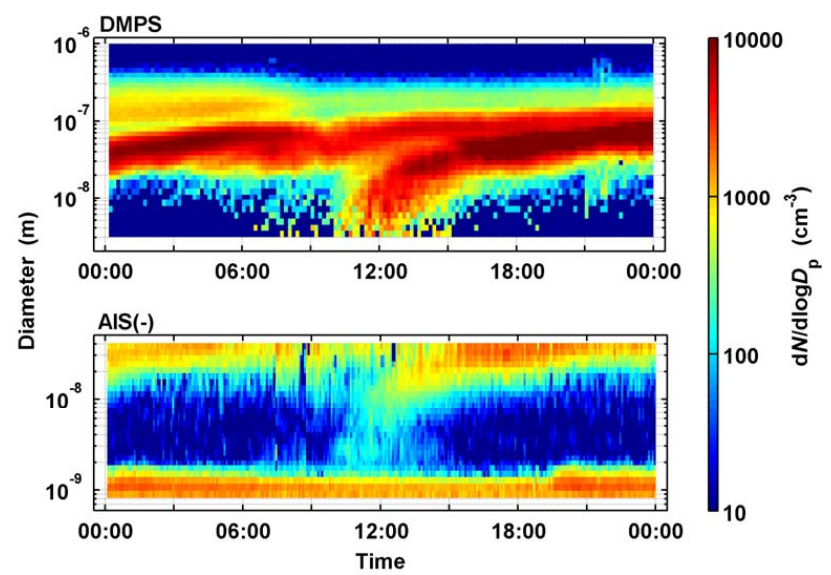

Fig. 3. A particle formation event on 5 July 2006 at the SMEAR II station in Hyytiälä, Finland. The upper panel illustrates the total particle number size distribution as measured with the Differential Mobility Sizer (DMPS) system. The lower panel depicts the corresponding size distributions of the air ions, recorded with an Air Ion Spectrometer (AIS). New particles are formed around noon and they grow towards $\mathrm{CCN}$ sizes during the course of the day.

inlet with about $30 \mathrm{~mm}$ of inner diameter facing forward in flight direction. Inside the aircraft we had a valve that made it possible to close the inlet completely. The instrument was connected to the inlet by about $1 \mathrm{~m}$ of tube with $\sim 30 \mathrm{~mm}$ inner diameter. During the campaign we added a cone with a 6-mm diameter hole in front of the pipe to reduce the effect of ramp pressure while gradually slowing down the air without creating turbulence. This decreased the measurement noise. The instrument operated as expected. The airflows were correctly controlled up to the 8-km altitude. Above that the sheath flow pumps were unable to provide the required flow rate. This caused the measurement range of the instrument to shift towards larger particles. The size shift was corrected for in the post-processing of the data. We are aware that some uncertainty to the particle charge distribution is also introduced by the potential effects of applying the inlet at high speed and reduced pressure. A detailed analyses of these phenomena, however, is left for a future study. For the details of the measurement campaign, the reader is deirected to the article by Mirme et al. (2010).

\section{Results}

We start our analysis by comparing 13 years (1996-2008) of atmospheric aerosol size distribution data from the SMEAR II station in Hyytiala, Finland, to the corresponding time series of galactic CRII. An example of a typical atmospheric particle formation event day at the SMEAR II station is shown in Fig. 3, which illustrates the evolution of the size distribution of the total aerosol population (recorded with the DMPS) as well as the corresponding distribution of air ions 
Table 1. List of DLR Falcon instrumentation during the EUCAARI-LONGREX campaign in May 2008.

\begin{tabular}{|c|c|}
\hline Instrument & Measured parameters \\
\hline $\begin{array}{l}\text { WALES High Spectral Resolution } \\
\text { Lidar (HRSL) }\end{array}$ & $\begin{array}{l}\text { Extinction profile at } 532 \mathrm{~nm} \text {, backscatter at } \\
532,925 \text { and } 1064 \mathrm{~nm} \text {, water vapor at } \\
532 \mathrm{~nm} \text {, aerosol depolarization }\end{array}$ \\
\hline 5-channel CPC system (unheated/heated) & $\begin{array}{l}\text { Total particle number concentration }>10 \mathrm{~nm} \\
\text { (volatile/non-volatile), ultrafine particles } \\
4-10 \mathrm{~nm}\end{array}$ \\
\hline $\begin{array}{l}\text { 2-channel Grimm } 1.129 \text { OPC } \\
\text { (unheated/heated) }\end{array}$ & $\begin{array}{l}\text { Particle size distribution } 0.25-2 \mu \mathrm{m} \\
\text { (volatile/non-volatile) }\end{array}$ \\
\hline $\begin{array}{l}\text { PCASP-100X, FSSP-300 aerosol } \\
\text { spectrometers }\end{array}$ & $\begin{array}{l}\text { Particle size distribution } 0.15-20 \mu \mathrm{m} \text { and } \\
\text { cloud elements }\end{array}$ \\
\hline $\mathrm{CO}$ & Carbon monoxide mixing ratio \\
\hline Ozone & Ozone mixing ratio \\
\hline Falcon "meteorological" data & $\begin{array}{l}\text { Position, wind, temperature etc., humidity } \\
\text { (up to } \sim 8 \mathrm{~km} \text { ) }\end{array}$ \\
\hline Broad-band radiometer & Longwave and shortwave radiation flux \\
\hline
\end{tabular}

Table 2. The binary correlation coefficients between monthly nucleation event numbers, nucleation event numbers normalised with the number of bright days, and monthly medians of cosmic ray ionisation intensity (CRII), brightness parameter, the $a a, K p$ and $\Delta B$ parameters describing the geomagnetic activity, particle formation and growth rates $\left(J_{3}\right.$ and $\left.G R\right)$, and particle concentrations in size ranges 3-25 nm, 25-100 nm and 100-1000 nm $\left(N_{3-25}, N_{25-200}, N_{100-1000}\right)$ during 1996-2008. The corresponding $p$-values are indicated in parentheses. The total number of data points in the first and third column is 155 , and in the second column 143.

\begin{tabular}{lccc}
\hline & Number of nucleation events & $\begin{array}{c}\text { Number of events/ } \\
\text { number of bright days }\end{array}$ & CRII $\left(\mathrm{cm}^{-3} \mathrm{~s}^{-1}\right)$ \\
\hline CRII $\left(\mathrm{cm}^{-3} \mathrm{~s}^{-1}\right)$ & $-0.14(0.09)$ & $-0.04(0.69)$ & - \\
Brightness parameter & $0.60\left(<10^{-10}\right)$ & - & $-0.09(0.27)$ \\
$a a(\mathrm{nT})$ & $0.11(0.15)$ & $0.20\left(1.9 \cdot 10^{-2}\right)$ & $-0.65\left(<10^{-10}\right)$ \\
$K p$ & $0.14(0.09)$ & $0.13(0.12)$ & $-0.68\left(<10^{-10}\right)$ \\
$\Delta B(\mathrm{nT})$ & $0.38\left(1.1 \cdot 10^{-6}\right)$ & $0.10(0.27)$ & $-0.65\left(<10^{-10}\right)$ \\
$J_{3}\left(\mathrm{~cm}^{-3} \mathrm{~s}^{-1}\right)$ & $0.39\left(1.5 \cdot 10^{-5}\right)$ & $0.013(0.90)$ & $0.05(0.63)$ \\
$G R\left(\mathrm{~nm} \mathrm{~h}^{-1}\right)$ & $-0.11(0.23)$ & $-0.17(0.08)$ & $-0.08(0.41)$ \\
$N_{3-25 n m}\left(\mathrm{~cm}^{-3}\right)$ & $0.69\left(<10^{-10}\right)$ & $0.19(0.03)$ & $-0.16(0.04)$ \\
$N_{25-100 n m}\left(\mathrm{~cm}^{-3}\right)$ & $0.66\left(<10^{-10}\right)$ & $-0.03(0.73)$ & $-0.19(0.02)$ \\
$N_{100-1000 n m}\left(\mathrm{~cm}^{-3}\right)$ & $0.11(0.18)$ & $-0.35\left(3.7 \cdot 10^{-5}\right)$ & $-0.16(0.05)$ \\
\hline
\end{tabular}

(recoded by the Air Ion Spectrometer; Mirme et al., 2007). From the DMPS data, the formation of a new particle population and their growth to $\mathrm{CCN}$ sizes can be clearly seen. The AIS data, on the other hand, additionally shows the presence of the continuous cluster ion mode, a fraction of which is produced by the CRII.

The time series of annual-mean number of particle formation events and annual-median value of CRII are presented in Fig. 4a. On a monthly basis, the corresponding time series and scatter plot are shown in Fig. $4 \mathrm{~b}$ and c, respectively. No visible connection between the frequency of atmospheric new particle formation and CRII at the SMEAR II station over the investigated solar cycle can be seen. Statistically, these two quantities showed either no correlation or even anti-correlation, the correlation coefficients being $-0.60(p=0.03)$ on a yearly basis and $-0.14(p=0.08)$ on a monthly basis (see Table 2). Same is true also in the case where the "failed events" from years 1996-2006 are included in the analysis (Fig. 5). 
a)

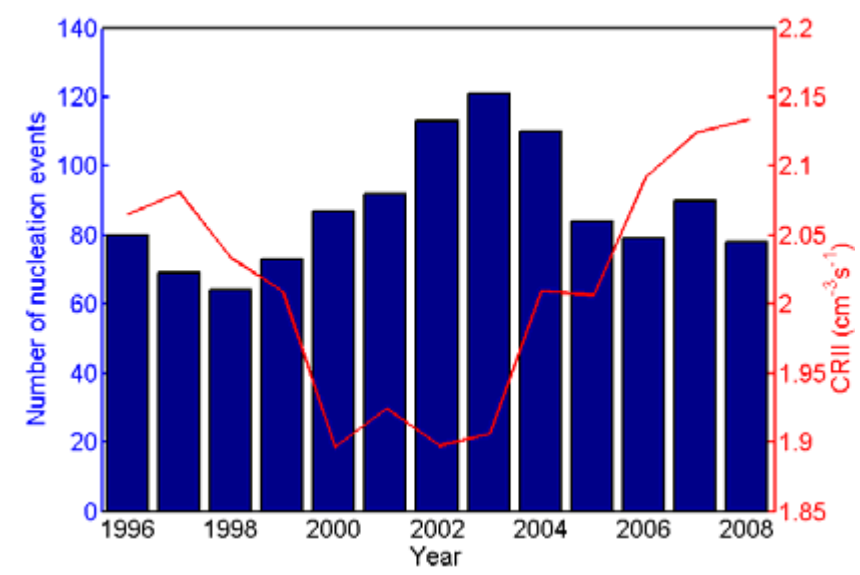

b)

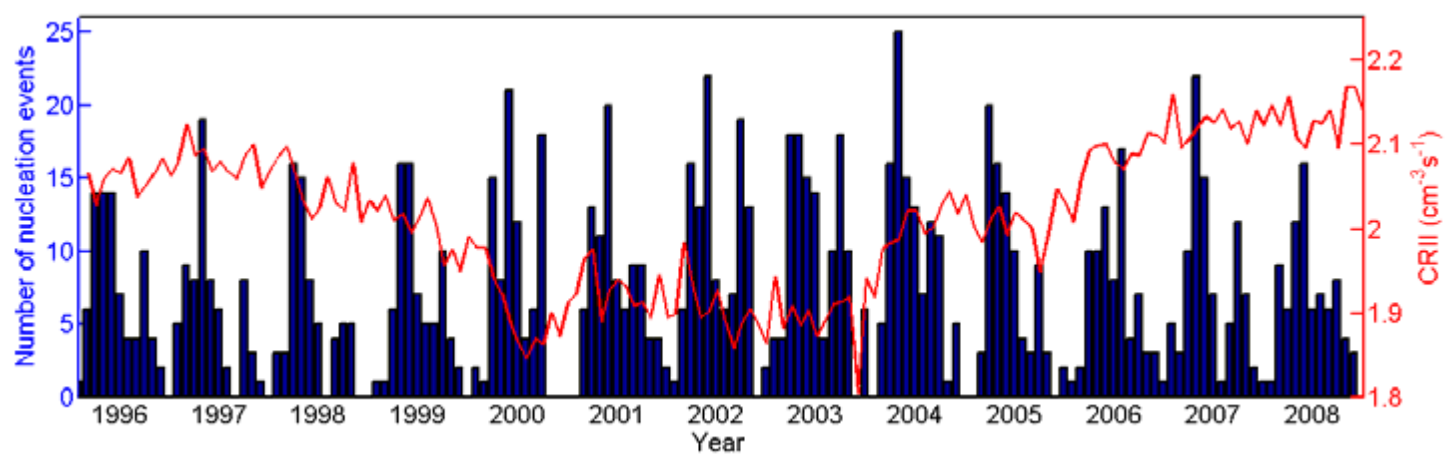

c)

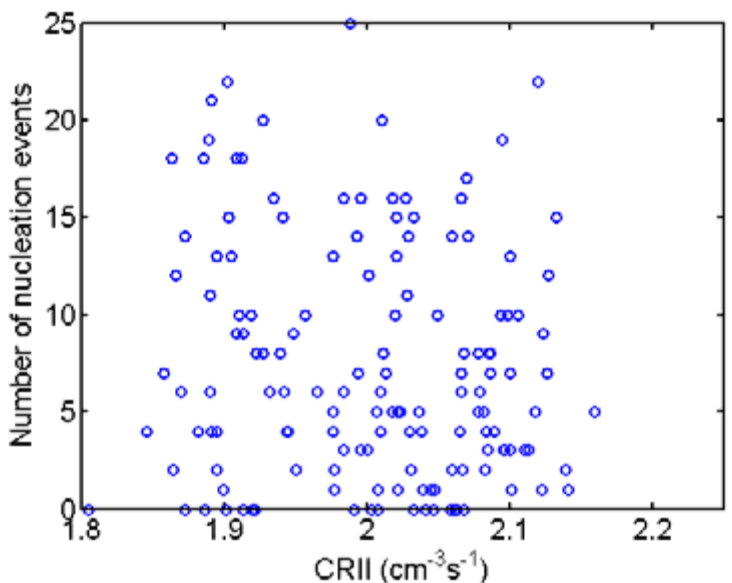

Fig. 4. Particle formation events and CRII at the SMEAR II station in Hyytiälä, Finland during 1996-2008. (a) The yearly numbers of particle formation events (blue bars) and the yearly median values of CRII (red line); (b) The monthly numbers of particle formation events (blue bars) and the corresponding monthly median values of CRII (red line); (c) The monthly number of particle formation events as a function of the corresponding median CRII. 


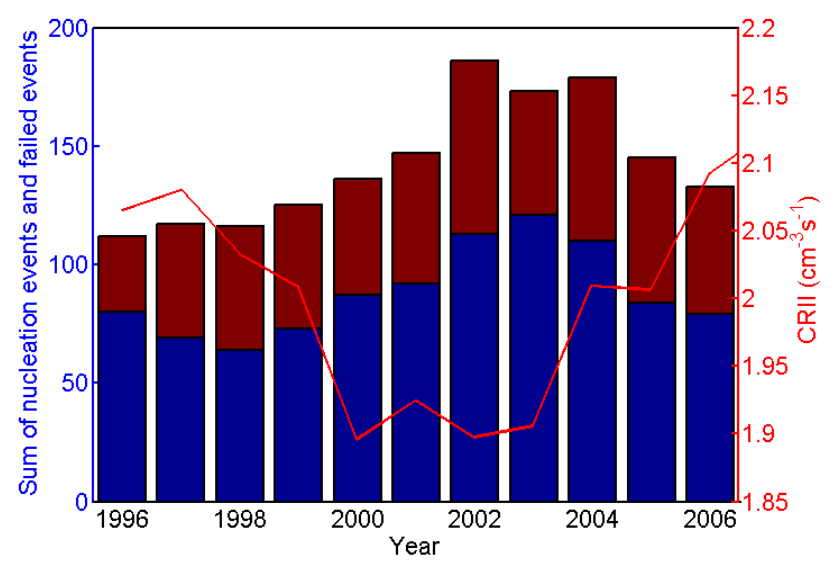

Fig. 5. The yearly numbers of nucleation events (blue bars), failed events as defined by Buenrostro Mazon et al. (2008) (red bars), and CRII (red line) at the SMEAR II station in Hyytiälä, Finland.

The frequency of aerosol formation events is not necessarily the best measure on atmospheric aerosol formation and its climatic influences. This is because (i) event frequencies may be biased due to observational limitations (such as abrupt air mass changes or the $3 \mathrm{~nm}$ cut-off size of the DMPS), (ii) the overall intensity of aerosol formation may vary from event to event, and (iii) the nucleated particles need to grow into sizes of at least $50-100 \mathrm{~nm}$ in diameter to be able to affect cloud properties. As a result, we repeated our analysis for the following quantities: the total number concentration of particles in the nucleation (diameter 3-25 nm, $N_{3-25}$ ), Aitken $\left(25-100 \mathrm{~nm}, N_{25-100}\right)$ and accumulation (100-1000 nm, $\left.N_{100-1000}\right)$ modes, the formation rate of $3 \mathrm{~nm}$ particles and growth rate of nucleation mode particles (GR in Table 2). None of these quantities showed a statistically significant correlation with CRII (see Figs. 6-7, Table 2). The 3-25 nm particle growth rates were calculated using the method outlined by Dal Maso et al. (2005).

The complete lack of correlation between CRII and atmospheric aerosol formation in our measurements necessitates us to investigate the reason for this observation. We start by looking at nucleation, the very first step of atmospheric aerosol formation. Figure 8 shows the contribution of ioninduced nucleation to the total nucleation rate, as measured at the three field sites. According to this approach, the total nucleation rate can be expressed as the sum of neutral and ion-induced nucleation rates, also including the contribution of ion-ion recombination to neutral particle formation rate, i.e.

$$
J_{\text {total }}=J_{\text {neutral }}+J_{\text {ions }}+J_{\text {recombination }}
$$

The charged fraction of the $2 \mathrm{~nm}$ particle formation rates at three ground-based measurement sites (Hyytiälä, Finland; Hohenpeissenberg, Germany, Melpitz, Germany; see Fig. 1) were calculated using the NAIS and AIS data using the a)

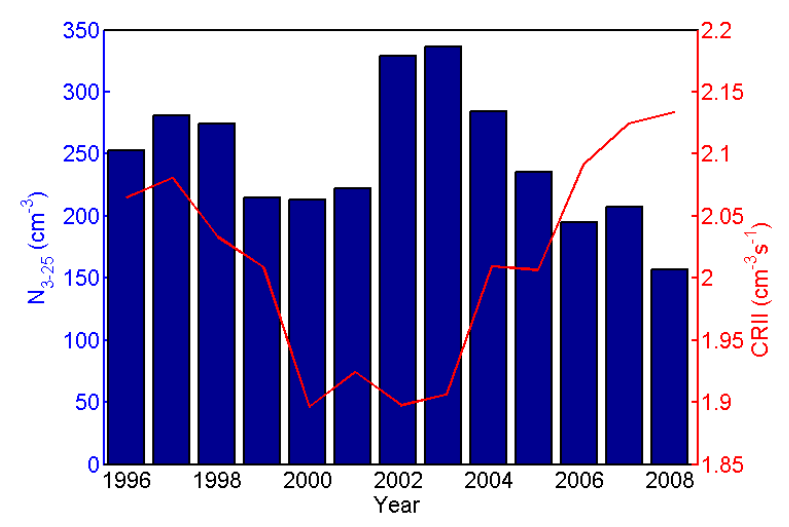

b)

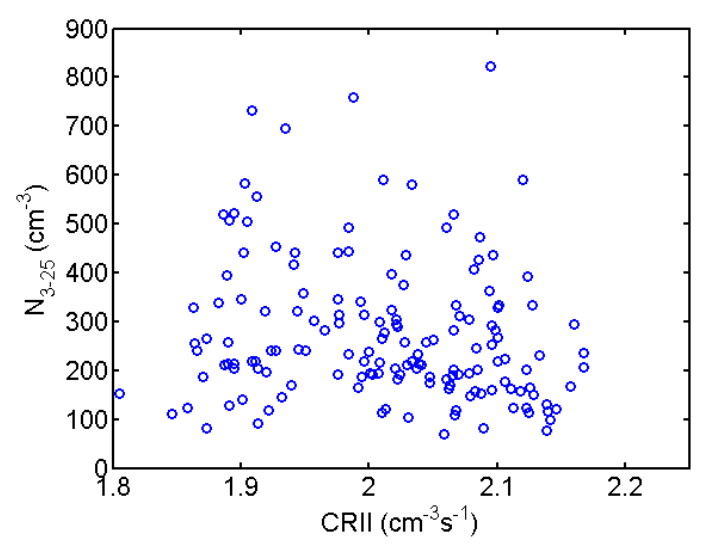

Fig. 6. Nucleation mode particle number concentrations $\left(N_{3-25}\right)$ and CRII at the SMEAR II station in Hyytiälä, Finland during 1996-2008. (a) Yearly medians of $N_{3-25}$ (blue bars) and CRII (red line); (b) Monthly medians of $N_{3-25}$ as a function of CRII.

method described by Manninen et al. (2009). While ioninduced nucleation may dominate atmospheric aerosol formation under specific conditions, Fig. 8 demonstrates that such conditions are confined to low aerosol formation rates. As a result, the overall contribution of ion-induced nucleation to atmospheric aerosol formation seems to be small, being typically much less than $10 \%$. This finding is consistent with other field studies conducted at various continental boundary layers (Iida et al., 2006; Kulmala et al., 2007; Gagné et al., 2008; Manninen et al., 2009). We also performed airborne measurements using DLR Falcon aircraft with airborne NAIS. Figure 9 depicts the neutral and charged fractions of atmospheric aerosol particles in the $2.5-3 \mathrm{~nm}$ and $4-10 \mathrm{~nm}$ size ranges as a function of altitude in the tropospheric column. In general, both the charged and total particle concentrations in the size range $4-10 \mathrm{~nm}$ showed distinct vertical profiles, with a maximum below $2 \mathrm{~km}$ and a minimum between about 4 and $6 \mathrm{~km}$, which is consistent with 
a)

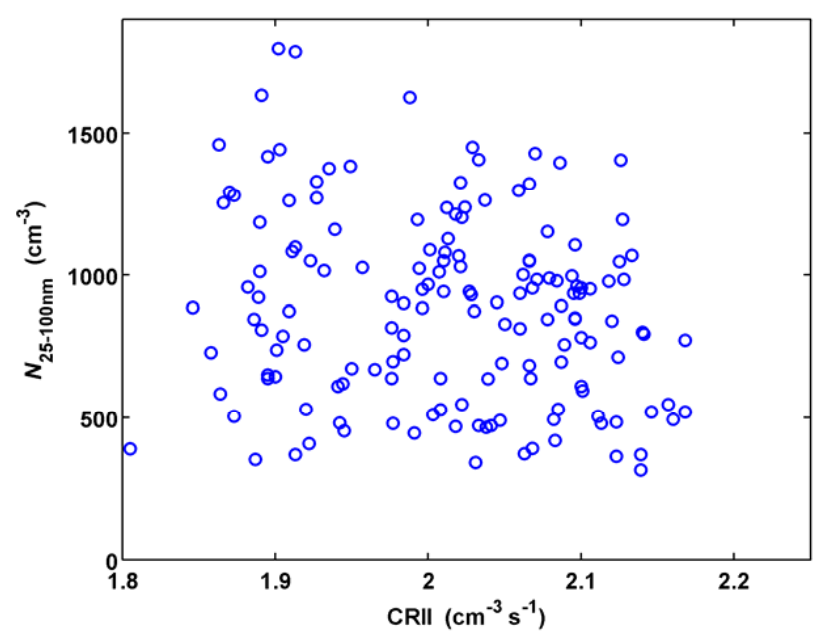

b)

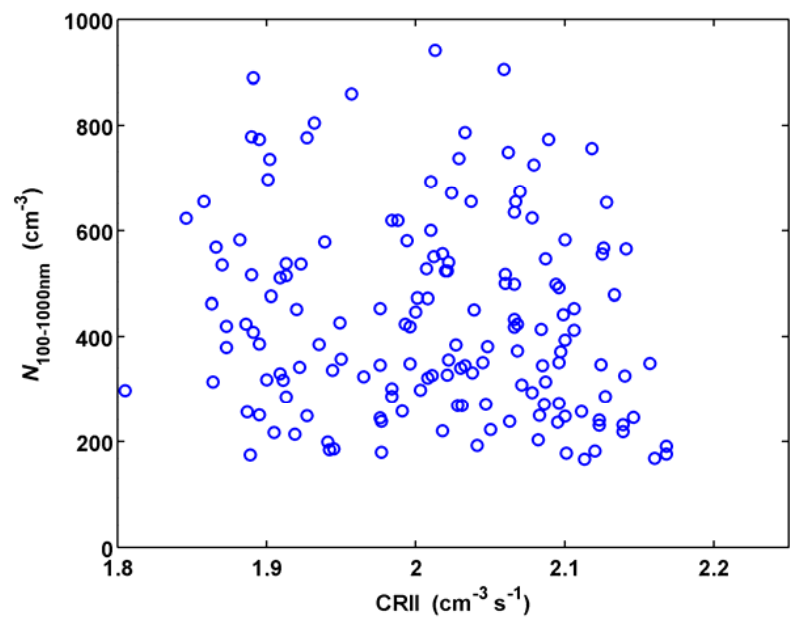

Fig. 7. Monthly medians of (a) $25-100 \mathrm{~nm}$; (b) $100-1000 \mathrm{~nm}$ particle concentrations as a function of CRII at the SMEAR II station in Hyytiälä, Finland.

earlier observations. $2.5-3 \mathrm{~nm}$ particles depicted a similar height profile, except the region above $8 \mathrm{~km}$, where the concentration ratio of charged particles to total concentration is decreasing. We can see that the number concentration of neutral clusters is, on average, 50 to 200 times higher than the concentration of charged clusters in the sub $3 \mathrm{~nm}$ size range. This suggests that the low contribution of ion-induced nucleation to total nucleation is valid for the whole tropospheric column.

The cosmic ray-induced flux of charged particle into the Earth's lower atmosphere varies by about $15 \%$ at high latitudes over a solar cycle, as driven by solar wind (Bazilevskaya et al., 2008). By combining this information with the typical ion-induced contribution of less than $10 \%$,

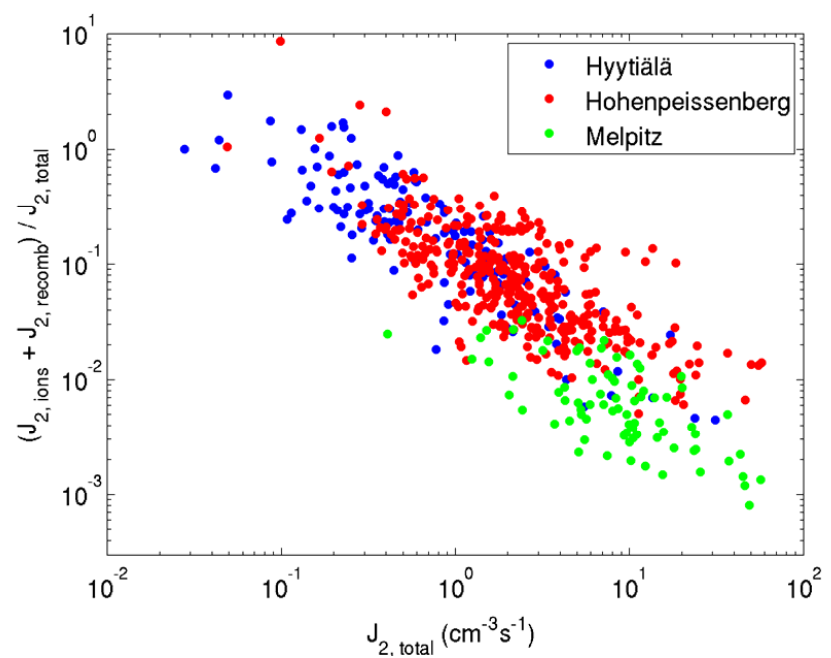

Fig. 8. The contribution of ions including ion-ion recombination on atmospheric nucleation rate as a function of total nucleation rate. Every data point represents half an hour average during nucleation event. Nucleation rates were determined using NAIS from 3 different continental boundary layer sites. Melpitz, Germany, is a polluted site, and Hohenpeissenberg, Germany, is a relatively clean mountain site.
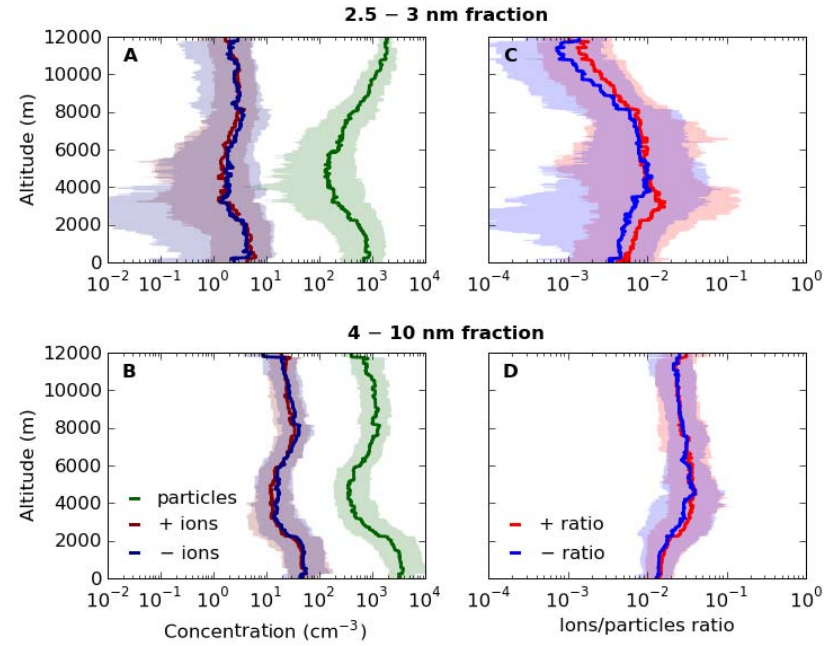

Fig. 9. Median concentration profiles of total (green) and charged (red and blue) clusters and particles in size ranges $2.5-3 \mathrm{~nm}$ (A) and $4-10 \mathrm{~nm}(\mathbf{B})$, as well as the corresponding concentration ratios between charged and total particles - $(\mathbf{C})$ and (D), derived from measurements from all flights in May 2008 over Central Europe. Solid line shows the median over all measurement flights, while the shading represents 25 and $75 \%$ percentiles of the data.

we estimate that changes in CRII could induce a maximum change of $1.5 \%$ in the formation of atmospheric aerosols over a solar cycle. The corresponding change in the formation of cloud condensation nuclei $(\mathrm{CCN})$ would be much less than $1 \%$, since the contribution of atmospheric nucleation to total 
a)

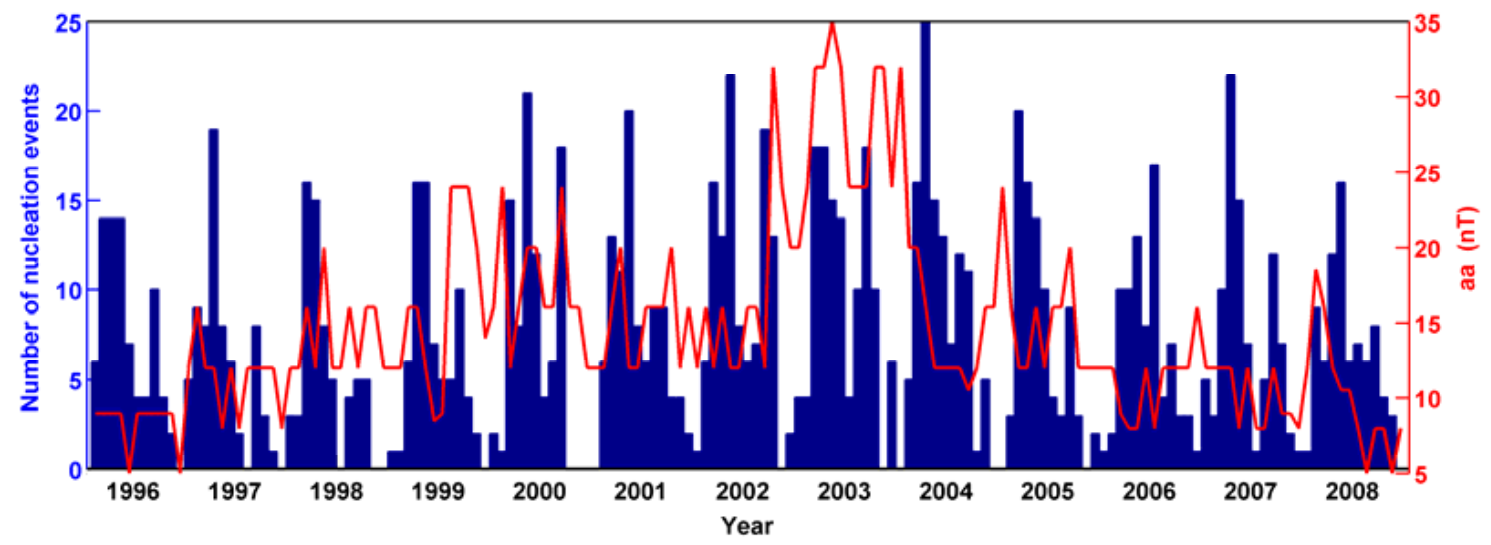

b)

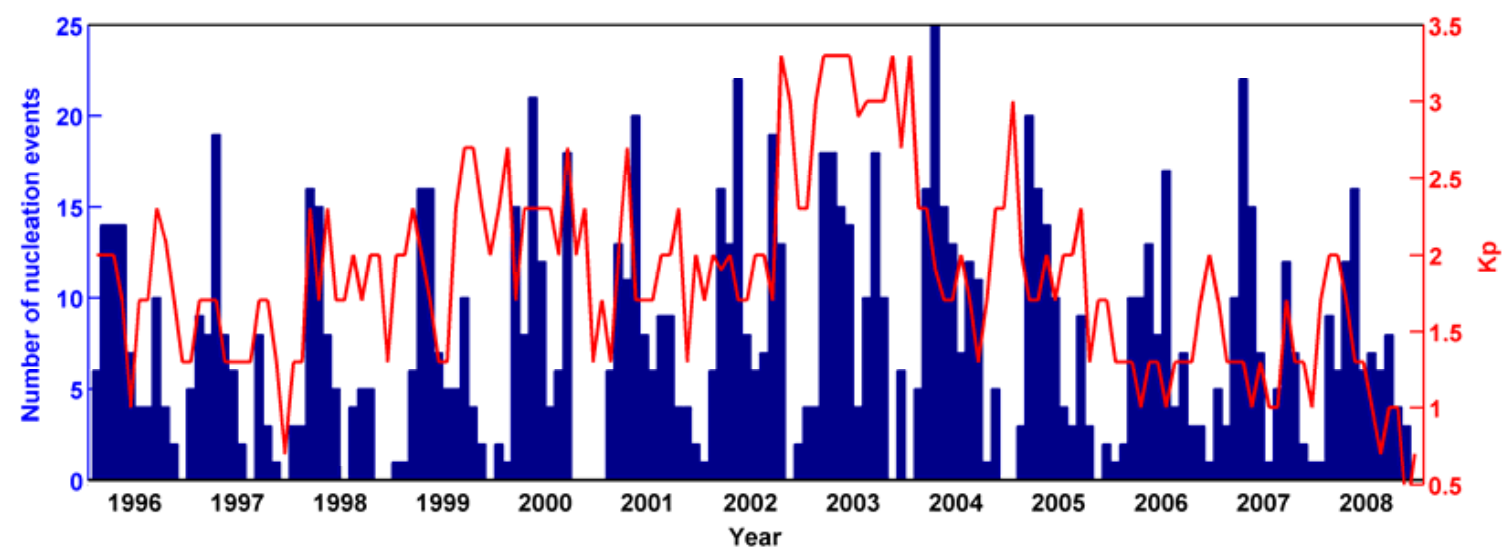

c)

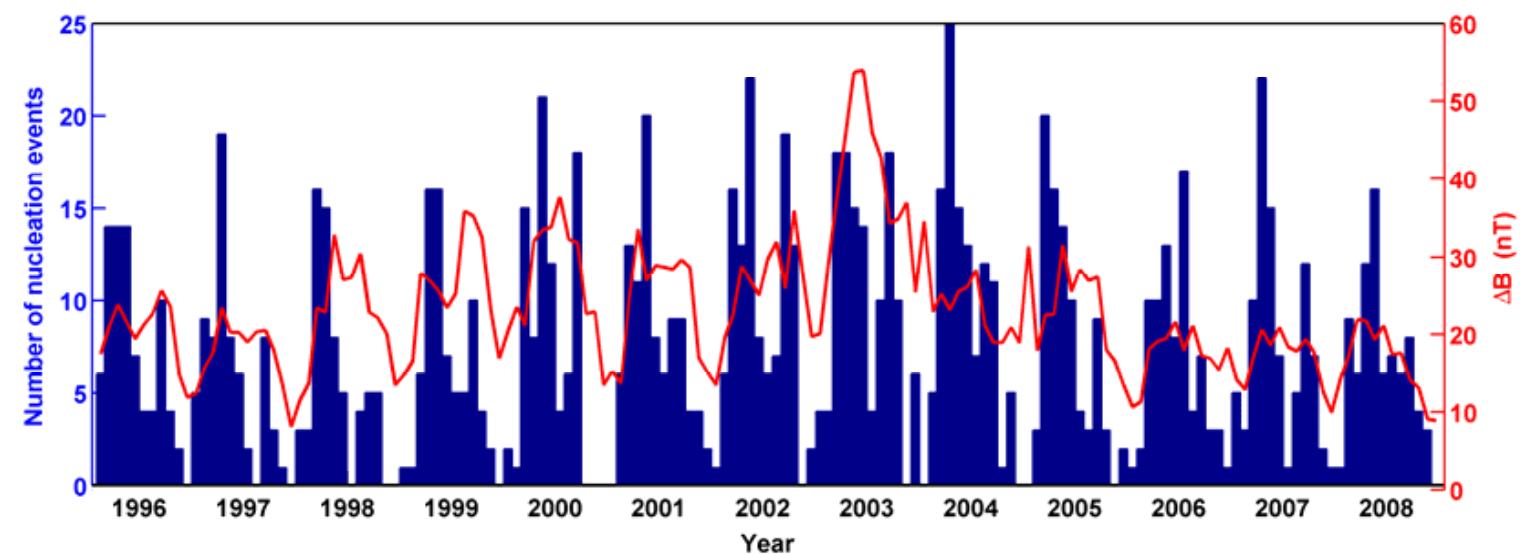

Fig. 10. Monthly numbers of nucleation events (bars) in years 1996-2008 and the median monthly values of the parameters (a) $a a$; (b) $K p$; (c) $\Delta B$ related to the geomagnetic activity (red lines). 
a)

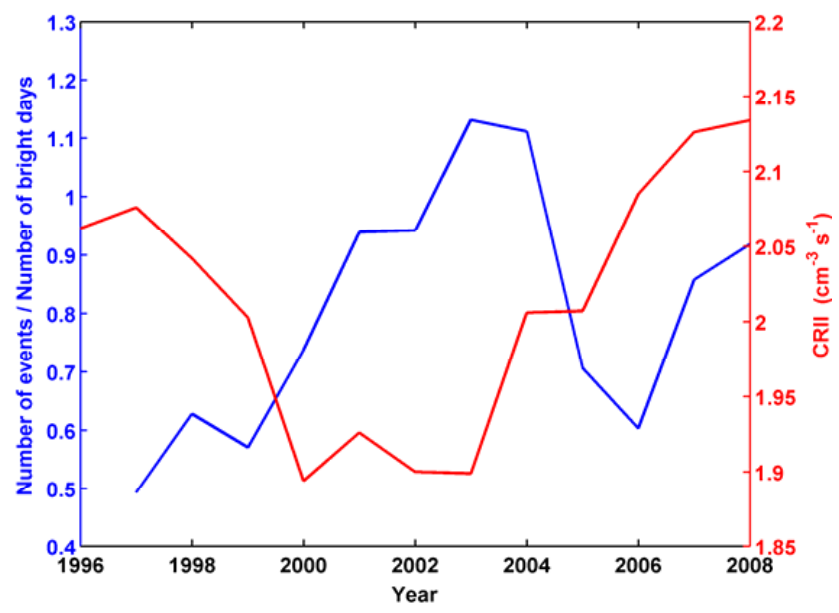

b)

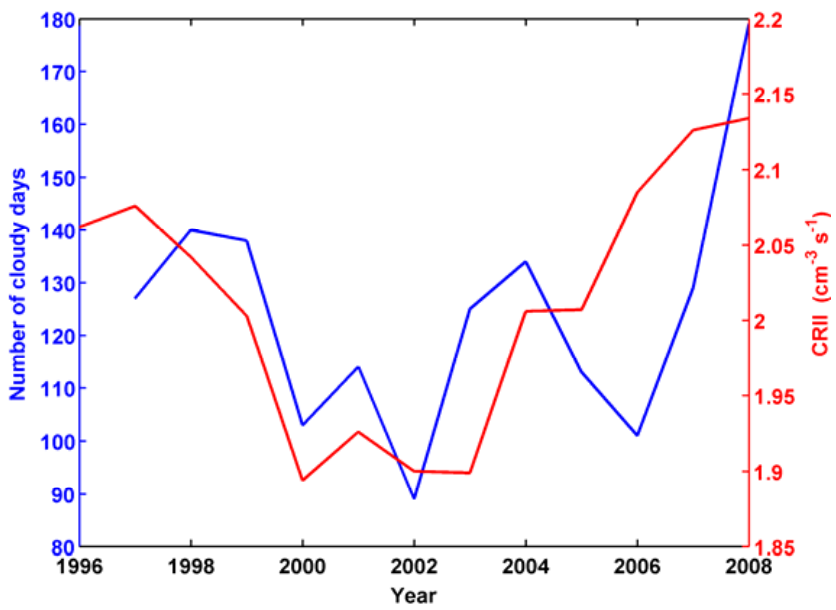

Fig. 11. (a) The yearly numbers of nucleation event days normalized with the numbers of bright (brightness parameter $P>0.5$ ) days (19972008 , blue line) and the yearly median cosmic ray ionisation intensity (1996-2007); (b) The yearly number of cloudy (brightness parameter $P<0.3)$ days and the yearly median cosmic ray ionisation intensity (1996-2008).

aerosol concentration has been seen to be bigger than its contribution to CCN production (Spracklen et al., 2008). Recently, Pierce and Adams (2009) ended up with a similar result using a global chemical transport model.

Besides cosmic-ray induced effects, changes in the global atmospheric electric circuit related to solar-activity driven geomagnetic activity have been proposed as mechanisms affecting cloud microphysics (Tinsley, 2000). Therefore, also parameters related to geomagnetic activity, namely $a a, K p$ and $\Delta B$, were investigated for the years 1996-2008. However, no or minor correlation between the geomagnetic activity and either $N_{3-25}$ or event frequency was observed (Fig. 10 and Table 2).
Finally, we investigated whether a connection between nucleation events, CRII and cloudiness estimated from seasonally normalized global (solar) radiation at the SMEAR II station (years 1996-2008) could be seen (see Fig. 11, Table 2). No clear connection between CRII and nucleation event normalised with bright days was observed. CRII and cloudiness did not show a significant correlation either. Nucleation event frequencies were, however, positively correlated with the normalized global radiation (Fig. 12). Such a correlation is expected, pointing toward the photochemical production of vapors participating in atmospheric aerosol formation (Kulmala et al., 2004). 


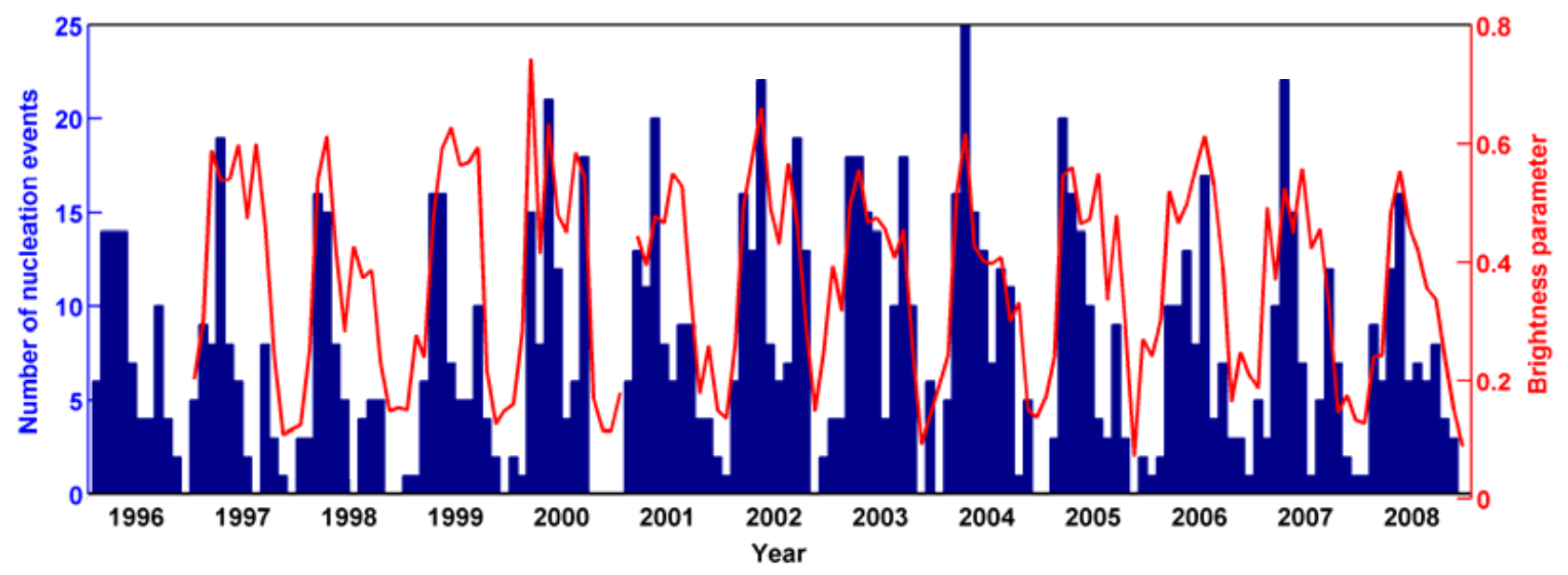

Fig. 12. Monthly numbers of nucleation events (blue bars) and the median monthly values of the brightness parameter $P$ for years $1997-2008$ (red line).

\section{Conclusions}

Galactic cosmic rays and the related ion-induced nucleation have been proposed to be among the key factors governing atmospheric aerosol budgets and subsequently cloudiness and global climate. Here we have shown, based on long-term experimental data, that atmospheric nucleation frequency or nucleation mode particle concentrations do not show correlation with galactic cosmic rays on either yearly or monthly basis. The geomagnetic activity showed similar seasonal behaviour as nucleation event frequencies, peaking in spring and autumn, but this similarity seems to be caused by different reasons. Accordingly, no significant daily correlation between these variables was found. Our results do not support the idea that the ions produced by galactic cosmic rays would be a major factor behind secondary aerosol production and the related aerosol-cloud interactions.

Acknowledgements. The authors kindly acknowledge funding from the European Commissions 6th Framework project EUCAARI (European Integrated project on Aerosol Cloud Climate and Air Quality Interactions, No 036833-2). I. R. acknowledges Maj and Tor Nessling foundation (grant number 2009257) for financial support.

Edited by: A. Wiedensohler

\section{References}

Aalto, P., Hämeri, K., Becker, E., Weber, R., Salm, J., Mäkelä, J. M., Hoell, C., O’Dowd, C. D., Karlsson, H., Hansson, H.-C., Väkevä, M., Koponen, I. K., Buzorius, G., and Kulmala, M.: Physical Characterization of aerosol particles during nucleation events, Tellus, 53B, 344-358, 2001.

Baker, M. B. and Peter, T.: Small-scale cloud processes and climate, Nature, 451, 299-300, 2008.
Bazilevskaya, G. A., Usoskin, I. G., Flückiger, E. O., Harrison, R. G., Desorgher, L., Bütikofer, R., Krainev, M. B., Makhmutov, V. S., Stozhkov, Y. I., Svirzhevskaya, A. K., Svirzhevsky, N. S., and Kovaltsov, G. A.: Cosmic ray induced ion production in the atmosphere, Space Sci. Rev., 137, 149-173, 2008.

Birmili, W., Wiedensohler, A., Plass-Dülmer, C., and Berresheim, H.: Evolution of newly formed aerosol particles in the continental boundary layer: A case study including $\mathrm{OH}$ and $\mathrm{H}_{2} \mathrm{SO}_{4}$ measurements, Geophys. Res. Lett., 27, 2205-2208, 2000.

Birmili, W., Schepanski, K., Ansmann, A., Spindler, G., Tegen, I., Wehner, B., Nowak, A., Reimer, E., Mattis, I., Müller, K., Brüggemann, E., Gnauk, T., Herrmann, H., Wiedensohler, A., Althausen, D., Schladitz, A., Tuch, T., and Löschau, G.: A case of extreme particulate matter concentrations over Central Europe caused by dust emitted over the southern Ukraine, Atmos. Chem. Phys., 8, 997-1016, 2008,

http://www.atmos-chem-phys.net/8/997/2008/.

Buenrostro Mazon, S., Riipinen, I., Schultz, D. M., Valtanen, M., Dal Maso, M., Sogacheva, L., Junninen, H., Nieminen, T., Kerminen, V.-M., and Kulmala, M.: Classifying previously undefined days from eleven years of aerosol-particle-size distribution data from the SMEAR II station, Hyytiälä, Finland, Atmos. Chem. Phys., 9, 667-676, 2009, http://www.atmos-chem-phys.net/9/667/2009/.

Carslaw, K. S., Harrison, R. G., and Kirkby, J.: Cosmic rays, clouds, and climate, Science, 298, 1732-1737, 2002.

Clement, A. C., Burgman, R., and Norris, J. R.: Observational and model evidence for positive low-level cloud feedback, Science, 325(5939), 460-464, doi:10.1126/science.1171255, 2009.

Dal Maso, M., Sogacheva, L., Aalto, P. P., Riipinen, I., Komppula, M., Tunved, P., Korhonen, L., Suur-Uski, V., Hirsikko, A., Kurten, T., Kerminen, V.-M., Lihavainen, H., Viisanen, Y., Hansson, H.-C., and Kulmala, M.: Formation and growth of fresh atmospheric aerosols: eigth years of aerosol size distribution data from SMEAR II, Hyytiälä, Finland, Boreal Environ. Res., 10, 323-336, 2005.

Dickinson, R. E.: Solar variability and the lower atmosphere, B. Am. Meteor. Soc., 56, 1240-1248, 1975. 
Engler, C., Rose, D., Wehner, B., Wiedensohler, A., Brüggemann, E., Gnauk, T., Spindler, G., Tuch, T., and Birmili, W.: Size distributions of non-volatile particle residuals $\left(\mathrm{D}_{\mathrm{p}}<800 \mathrm{~nm}\right)$ at a rural site in Germany and relation to air mass origin, Atmos. Chem. Phys., 7, 5785-5802, 2007, http://www.atmos-chem-phys.net/7/5785/2007/.

Gagné, S., Laakso, L., Petäjä, T., Kerminen, V.-M., and Kulmala, M. : Analysis of one year of Ion-DMPS data from the SMEAR II station, Finland, Tellus, 60B, 318-329, 2008.

Gleeson, L. J. and Axford, W. I.: Solar modulation of galactic cosmic rays, Astrophys. J., 154, 1011-1026, 1968.

Hari, P. and Kulmala, M.: Station for Measuring EcosystemAtmosphere relations, Boreal Environ. Res., 10, 315-322, 2005.

Harrison, R. G. and Stephenson, D. B.: Empirical evidence for a nonlinear effect of galactic cosmic rays on clouds, Philos. T. R. Soc. A, 462, 1221-1223, 2006.

Hartman, D. L:. Global Physical Climatology, Academic Press, $411 \mathrm{~s}, 1994$.

Hirsikko, A., Paatero, J., Hatakka, J., and Kulmala, M.: ${ }^{222}$ Rn activity concentration, external radiatio dose and air ion production rates in a boreal forest in Finland between March 2000 and June 2006, Boreal Environ. Res., 12, 265-278, 2007.

Hock, N., Schneider, J., Borrmann, S., Römpp, A., Moortgat, G., Franze, T., Schauer, C., Pöschl, U., Plass-Dülmer, C., and Berresheim, H.: Rural continental aerosol properties and processes observed during the Hohenpeissenberg Aerosol Characterization Experiment (HAZE2002), Atmos. Chem. Phys., 8, 603-623, 2008, http://www.atmos-chem-phys.net/8/603/2008/.

Iida, K., Stolzenburg, M., McMurry, P., Dunn, M. J., Smith, J. N., Eisele, F., and Keady, P.: Contribution of ion-induced nucleation to new particle formation: Methodology and its application to atmospheric observations in Boulder, Colorado, J. Geophys. Res., 111, D23201, doi:1029/2006JD007167, 2006.

IPCC: The Scientific Basis: A report of Working Group I of the Intergovernmental Panel on Climate Change, in: Climate Change 2007: The Physical Science Basis, Contribution of Working Group I to the Fourth Assessment Report of the Intergovernmental Panel on Climate Change, edited by: Solomon, S., Qin, D., Manning, M., Chen, Z., Marquis, M., Averyt, K. B., Tignor, M., and Miller, H. L., Cambridge University Press, Cambridge, UK and New York, NY, USA, 2007.

Jokinen, V. and Mäkelä, J. M.: Closed loop arrangement with critical orifices for DMA sheath/excess flow system, J. Aerosol Sci., 28, 643-648, 1997.

Kazil, J., Lovejoy, E. R., Barth, M. C., and O'Brien, K.: Aerosol nucleation over oceans and the role of galactic cosmic rays, Atmos. Chem. Phys., 6, 4905-4924, 2006,

http://www.atmos-chem-phys.net/6/4905/2006/.

Kristánsson, J. E., Stjern, C. W., Stordal, F., Fjæraa, A. M., Myhre, G., and Jónasson, K.: Cosmic rays, cloud condensation nuclei and clouds - a reassessment using MODIS data, Atmos. Chem. Phys., 8, 7373-7387, 2008,

http://www.atmos-chem-phys.net/8/7373/2008/.

Kulmala, M., Hämeri, K., Aalto, P. P., Mäkelä, J. M., Pirjola, L., Nilsson, E. D., Buzorius, G., Rannik, U., Dal Maso, M., Seidl, W., Hoffmann, T., Janson, R., Hansson, H.-C., Viisanen, Y., Laaksonen, A., and O'Dowd, C. D.: Overview of the international project on biogenic aerosol formation in the boreal forest
(BIOFOR), Tellus, 53B, 324-343, 2001.

Kulmala, M., Vehkamäki, H., Petäjä, T., Dal Maso, M., Lauri, A., Kerminen, V.-M., Birmili, W., and McMurry, P.: Formation and growth rates of ultrafine atmospheric particles: a review of observations, J. Aerosol Sci., 35, 143-176, 2004.

Kulmala, M., Riipinen, I., Sipilä, M., Manninen, H. E., Petäjä, T., Junninen, H., Dal Maso, M., Mordas, G., Mirme, A., Vana, M., Hirsikko, A., Laakso, L., Harrison, R. M., Hanson, I., Leung, C., Lehtinen, K. E. J., and Kerminen, V.-M.: Toward direct measurement of atmospheric nucleation, Science, 318(5847), 89-92, doi:10.1126/science.1144124, 2007.

Manninen, H. E., Nieminen, T., Riipinen, I., Yli-Juuti, T., Gagné, S., Asmi, E., Aalto, P. P., Petäjä, T., Kerminen, V.-M., and Kulmala, M.: Charged and total particle formation and growth rates during EUCAARI 2007 campaign in Hyytiälä, Atmos. Chem. Phys., 9, 4077-4089, 2009,

http://www.atmos-chem-phys.net/9/4077/2009/.

Mayaud, P. N.: Derivation, Meaning, and Use of Geomagnetic Indices, AGU, Washington, DC, 1980.

Minikin, A., Petzold, A., Ström, J., Krejci, R., Seifert, M., van Velthoven, P., Schlager, H., and Schumann, U.: Aircraft observations of the upper tropospheric fine particle aerosol in the Northern and Southern Hemispheres at midlatitudes, Geophys. Res. Lett., 30, 1503, doi:10.1029/2002GL016458, 2003.

Mirme, A., Tamm, E., Mordas, G., Vana, M., Uin, J., Mirme, S. Bernotas, T., Laakso, L., Hirsikko, A., and Kulmala, M.: A widerange multi-channel Air Ion Specrometer, Boreal Environ. Res., 12, 247-264, 2007.

Mirme, S., Mirme, A., Minikin, A., Petzold, A., Hõrrak, U., Kerminen, V.-M., and Kulmala, M.: Atmospheric sub-3 nm particles at high altitudes, Atmos. Chem. Phys., 10, 437-451, 2010, http://www.atmos-chem-phys.net/10/437/2010/.

Mäkelä, J. M., Aalto, P., Jokinen, V., Pohja, T., Nissinen, A., Palmroth, S., Markkanen, T., Seitsonen, K., Lihavainen, H., and Kulmala, M.: Observations of ultrafine aerosol particle formation and growth in boreal forest, Geophys. Res. Lett., 24, 1219-1222, 1997.

Mäkelä, J. M., Koponen, I. K., Aalto, P., and Kulmala, M.: Oneyear data of submicron size modes of tropospheric background aerosol in Southern Finland, J. Aerosol Sci., 31, 595-611, 2000.

Palle, E.: Possible satellite perspective effects on the reported correlations between solar activity and clouds, Geophys. Res. Lett., 32, L03802, doi:10.1029/2004GL021167, 2005.

Pierce, J. R. and Adams, P. J.: Can cosmic rays affect cloud condensation nuclei by altering new particle formation rates?, Geophys. Res. Lett., 36, L09820, doi:10.1029/2009GL037946, 2009.

Rangarayan, G. K.: Indices of Geomagnetic Activity, in: Geomagnetism, edited by: Jacobs, J. A., Academic Press, 3, 323-384, 1989.

Rohrer, F. and Berresheim, H.: Strong correlation between levels of tropospheric hydroxyl radicals and solar ultra-violet radiation, Nature, 442, 184-187, doi:10.1038/nature04924, 2006.

Sloan, T. and Wolfendale, A. W.: Testing the proposed causal link between cosmic rays and cloud cover, Environ. Res. Lett., 3, 1-6, 2008.

Sogacheva, L., Saukkonen, L., Nilsson, E. D., Dal Maso, M., Schultz, D., de Leeuw, G., and Kulmala, M.: New aerosol particle formation in different synoptic situations at Hyytiälä, southern Finland, Tellus, 60B, 485-494, 2008. 
Spracklen, D. V., Carslaw, K. S., Kulmala, M., Kerminen, V.-M., Sihto, S.-L., Riipinen, I., Merikanto, J., Mann, G. W., Chipperfield, P. M., Wiedensohler, A., Birmili, W., and Lihavainen, $\mathrm{H}$ :. Contribution of particle formation to global cloud condensation nuclei concentrations, Geophys. Res. Lett., 35, L06808, doi:10.1029/2007GL033038, 2008.

Sun, B. and Bradley, R. S.: Solar influences on cosmic rays and cloud formation: A reassessment, J. Geophys. Res., 107(D14), D14206, doi:10.1029/2001JD000560, 2002.

Svensmark, H. and Friis Christensen, E.: Variation of cosmic ray flux and global cloud coverage - A missing link in solar-climate relationships, J. Atmos. Sol.-Terr. Phy., 59, 1225-1232, 1997.

Svensmark, H., Bondo, T., and Svensmark, J.: Cosmic rays decreases affect atmospheric aerosols and clouds, Geophys. Res. Lett., 36, L15101, doi:10.1029/2009GL038429, 2009.

Tinsley, B. A.: Influence of Solar Wind on the Global Electric Circuit, and Inferred Effects on Cloud Microphysics, Temperature, and Dynamics in the Troposphere, Space Sci. Rev., 94, 231-258, 2000.

Usoskin, I. G., Alanko-Huotari, K., Kovaltsov, G. A., and Mursula, K.: Solar activity, cosmic rays, and Earth's temperature: A millennium-scale comparison, J. Geophys. Res., 110, A12108, doi:10.1029/2004JA010946, 2005.

Usoskin, I. G. and Kovaltsov, G. A.: Cosmic ray induced ionization in the atmosphere: Full modeling and practical applications, J. Geophys. Res., 111, D21206, doi:10.1029/2006JD007150, 2006.
Usoskin, I. G. and Kovaltsov, G. A.: Cosmic rays and climate of the Earth: Possible connection, Compt. Rend. Geosci., 340, 441450, 2008.

Usoskin, I. G., Laurent, D., Velinov, P., Storini, M., Flückiger, E. O., Bütikofer, R., Kovaltsov, G. A.: Ionization of the Earth's atmosphere by solar and galactic cosmic rays, Acta Geophys., 57, 88-101, 2009.

Weinzierl, B., Petzold, A., Esselborn, M., Wirth, M., Rasp, K., Kandler, K., Schütz, L., Koepke, P., Fiebig, M.: Airborne measurements of dust layer properties, particle size distribution and mixing state of Saharan dust during SAMUM 2006, Tellus, 61B, 96-117, 2009.

Winkler, P. M., Steiner, G., Vrtala, A., Vehkamäki, H., Noppel, M., Lehtinen, K. E. J., Reischl, G. P., Wagner, P. E., and Kulmala, M.: Heterogeneous nucleation experiments bridging the scale from molecular ion clusters to nanoparticles, Science, 319(5868), 1374-1377, doi:10.1126/science.1149034, 2008.

Yu, F., Wang, Z., Luo, G., and Turco, R.: Ion-mediated nucleation as an important global source of tropospheric aerosols, Atmos. Chem. Phys., 8, 2537-2554, 2008,

http://www.atmos-chem-phys.net/8/2537/2008/. 